\title{
Tackling Uncertainty in the Bio-Based Economy
}

Pasquale Marcello Falcone, Unitelma Sapienza - University of Rome, Rome, Italy \& Department of Business and Economics, Parthenope University of Naples, Naples, Italy

Enrica Imbert, Unitelma Sapienza - University of Rome, Rome, Italy

\begin{abstract}
There is a clear overall consensus among international institutions and governments on the need to scale down the reliance of the global economy on fossil fuels. Yet, a sustainable transition from a long-established regime based on rooted production and consumption models, requires tackling a wide array of challenges. Indeed, the transition towards a bio-based economy is still characterized by a high degree of complexity and uncertainty. Managing complexity and accounting for uncertainty entails appropriate and multidisciplinary tools. In this regard, sustainability certifications, standards and labels can play a pivotal role in navigating this transition, creating the conditions to ensure a level playing field between bio-based and conventional products.
\end{abstract}

\section{KEYWORDS}

Bio-Based Economy, Standards, Uncertainty

\section{INTRODUCTION}

There is a broad consensus among international institutions and governments of industrialized countries for the need to scale down the reliance of the global economy on fossil fuels, paving the way to a more responsible and resource efficient society (Dubois \& Gomez San Juan, 2016). This has increasingly led policy makers to pay greater attention to the bio-based economy (Staffas, Gustavsson, \& McCormick, 2013), representing one reliable way for transitioning to equitable, sustainable, post fossil-carbon societies (Ingrao et al., 2018). Though biomass has been consistently used as a raw material throughout history, it is only recently that, thanks to the development of new technologies (e.g. biorefineries), biomass deriving for instance from forestry and wood residues, biowaste, algae (Ben-Iwo, Manovic, \& Longhurst, 2016) or more traditional raw material such as agricultural biomass, has started to be exploited for obtaining a range of value-added products, (Imbert, 2017), although at varying stages of technical maturity, with some of them being commercially available and others still at the demonstration stage.

Many industries are thereby involved (e.g. agriculture and food, textile, wood and paper, chemical and pharmaceutical), together with an ever-increasing number of actors. These include farmers, waste management companies, converters, innovative startups and medium sized specialist producers as well as global brands (e.g., IKEA, Tetra Pak and Toyota) (Pöyry 2016). 
In addition to having a lower impact on the environment, the transition towards a bio-based economy, and more specifically to a circular bio-based economy, is also seen as a great opportunity to revive productivity and employment growth (European Commission, 2018b). Specifically, by improving the competitiveness of domestic industries through new technologies as well as by reducing dependence on imported feedstocks, also through the rehabilitation of marginalized lands and the exploitation of a wide variety of locally sourced wastes and residues that will be maximized by fully employing a cascading approach (Corrado \& Sala, 2018).

Several combined and interconnected issues, however, negatively affects the market entry of bio-based products. In this context, the implementation of a coherent yet, at the same time, flexible regulatory framework becomes a key factor in ensuring the sustainability of bio-based products (including impacts on health and safety and the environment), as well as improving the functioning of markets (European Commission, 2018a). Throughout this process, the development of standards would help to overcome the high degree of complexity and uncertainty that still surrounds the biobased economy and that will be discussed in this paper.

\section{TRANSITIONING TOWARDS A CIRCULAR BIO-BASED ECONOMY}

A sustainable transition from a long-established regime based on rooted production and consumption models, requires tackling a wide array of challenges. As stated by Priefer et al. (2017), despite the bio-based economy being viewed as a "comprehensive societal transition," a number of issues have not yet been fully addressed. In particular, besides rather well-known concerns surrounding the debate on the sustainability of the bioeconomy, including food security, land grabbing, direct and indirect land use changes (LUC and iLUC) and loss of biodiversity, additional issues highlighted by the literature must be taken into account. These include no level playing field with fossil based products, but also within the bio-based economy itself due to the incentives created by the EU's Renewable Energy Directives (RED I and II) and several member countries energy policies, intended for the use of biomass for energy production rather than for material purposes (Carus et al., 2016; Meyer, 2017). Moreover, there are only few product categories, such as bio-based lubricants, to have already benefited from regulatory measures at EU or Member State level (Spekreijse, Lammens, Parisi, Ronzon, \& Vis, 2019).

Another aspect that deserves particular attention is represented by demand-side developments, which include consumer willingness to pay for bio-based products and new consumer behavior towards sustainability and related changes in lifestyle. Notably, a major theme strongly interlinked with the bio-based economy is whether society can reach sustainability solely through the development of green innovative processes and products, or whether more far-reaching approaches, including lower consumption levels, should be implemented (Zsóka, Szerényi, Széchy, \& Kocsis, 2013). In recent years, several consumption and ownership models are indeed fast being developed (Priefer et al., 2017). These approaches include the extension of a product's life cycle by enabling recovery for repair or reuse and sharing model approaches (Martin, 2016) for example applied to cars (Mounce $\&$ Nelson, 2019) and food (Falcone \& Imbert, 2017; Morone, Falcone, Imbert, \& Morone, 2018). Remarkably, there are several issues debated in the literature such as whether the shift from a fossilbased economy will result in decreased productivity and whether a transition towards regenerative pathways inevitably leads to post-capitalist societies (Bosch \& Schmidt, 2019). This debate is also strongly related to the degrowth approach that views a voluntary reduction of overall consumption and production as the main target for societies in order to reach sustainability (Muradian, 2019).

\section{DEALING WITH RISK AND UNCERTAINTY IN BIO-BASED ECONOMY}

The notions of complexity and uncertainty are not consistent in literature and this produces confusion even among specialists (de Assis et al., 2017). Several definitions have been proposed to show how 
uncertainty could give rise to potentially negative impacts and thus risks (Aven, 2010). Specifically, the two concepts are mainly related to the context of capital investment decisions (Teece, Peteraf, \& Leih, 2016); "Uncertainty" relies on the existence of more than one value or the absence of information and being also related to randomness is one crucial element of the risk analysis (Hubbard, 2009). While a "Risk" is a random event disturbing the company purposes. If the impacts are positive, it is considered as an opportunity (Vose, 2008).

The bio-based industry is characterized by additional challenges in terms of risk and uncertainty, being in competition with a mature fossil-based system based on higher market efficiency. Relevant challenges for the bio-based industry relate to the availability and variability of feedstocks, the lack of data for the appraisal of socio-economic and environmental sustainability and the uncertainty surrounding the the market uptake of bio-based products (Falcone \& Imbert, 2018). Essentially, risk and uncertainty are related to four main key issues encompassing the bio-based economy, i.e.: i) the sustainability of bio-based products, ii), the costs and prices of conventional fossil based products iii) consumer acceptance and demand for bio-based products and iv) the bridging of the circular bio-based economy to other sustainable pathways.

\subsection{Sustainability of Bio-Based Products}

Firstly, the sustainability of bio-based products is a cross-cutting theme being crucial to both producers and consumers, as well as to policy makers. Part of the uncertainty related to bio-based products indeed surrounds the environmental, social and economic consequences generated by these kinds of products (Hagemann, Gawel, Purkus, Pannicke, \& Hauck, 2016). In particular, as for all new products, the uncertainty about the scale of the effects and the irreversibility of a number of them, should be properly considered (Turner, Pearce, \& Bateman, 1994). Accordingly, a comprehensive sustainability assessment is of paramount importance, given that bio-based products are not automatically sustainable (Pfau, Hagens, Dankbaar, \& Smits, 2014; Laibach et al. 2019). This implies that the full environmental, social and economic costs and benefits associated with bio-based products production should be well understood. Indeed, alongside the benefits, a broad range of possible side effects which could be even more harmful should be taken into consideration, to avoid the cure becoming worse than the disease (see on this Richardson, 2012; Sheppard et al., 2011).

An important concept strongly associated with bio-based products' sustainability is that the producers are responsible for what happens before and after the production stage. The analytical tools used for assessing products' sustainability should be necessarily consistent with this approach looking at the entire life cycle of a product (i.e. from extraction of raw materials to its end of life). Against this background, life cycle sustainability assessments (LCSAs) based on the combination of environmental life cycle assessment (ELCA), life cycle costing (LCC) and social life cycle assessment (SLCA) are considered the most effective way for assessing the environmental and socio-economic impacts of bio-based products (M. Martin, Røyne, Ekvall, \& Moberg, 2018). However, many limitations and weaknesses have been outlined, due to different definitions of bio-based products and the broad array of indicators and methods used (Falcone et al., 2019; Spierling et al., 2018).

Against this background, an intense standardization exercise was launched by the EU, in order to provide common guidelines for the classification and evaluation of bio-based products (Ladu \& Blind, 2017). More specifically, within the framework of its Lead Market Initiative aimed at boosting the market uptake of bio-based products, the European Commission issued a number of standardization mandates to the European Committee for Standardization (CEN), i.e. M/429 for the elaboration of a standardization program for bio-based products, M/430 on bio-polymers and bio-lubricants, M/491 on bio-solvents and bio-surfactants and M/492 for the development of horizontal standards for bio-based products. As shown by Figure 1, several CEN technical committees are in charge of the afore-mentioned mandates. 
Figure 1. CEN's technical committees engaged with bio-based product (Source: Adapted from Ladu and Blind (2017))

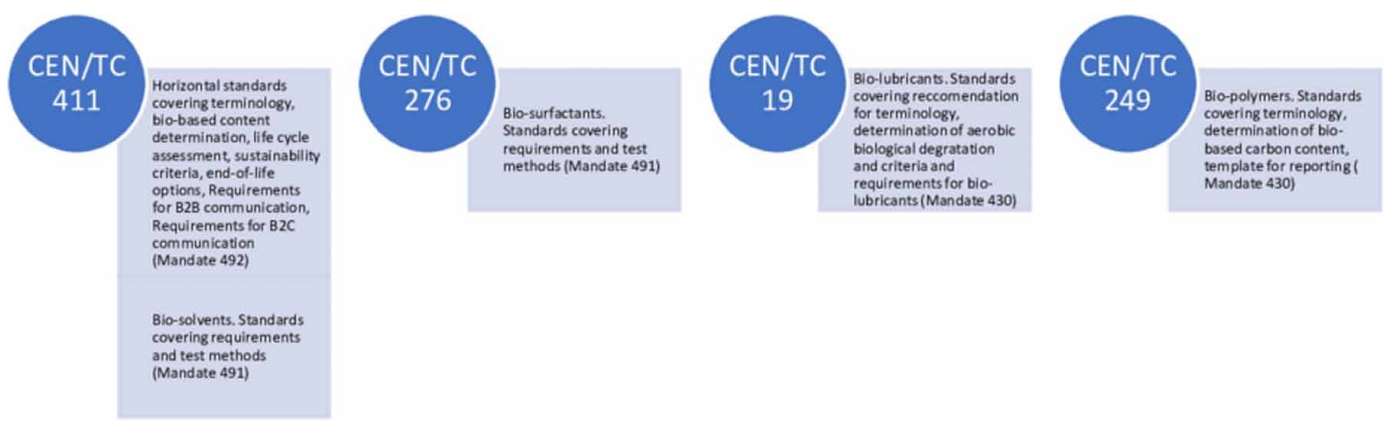

\subsection{Costs and Prices of Conventional Fossil-Based Products}

Better market penetration of new bio-based products necessitates a clear improvement regarding sustainability assessment, as well a sufficient techno-economic positioning compared to fossil-based products (van den Oever \& Molenveld, 2017). The large-scale utilization of such products creates some of the major market failures ${ }^{1}$ on the planet, especially when the focus is on abiotic resources (Farley \& Daly, 2011). There are conditions, in the ways fossil-based markets operate, violating one or more neoclassical economic assumptions that define an ideal market for products or services such as rational behavior, costless transactions, and perfect information (Brown, 2001). The price of fossil-based products does not accurately represent the cost of their production. Therefore, it does not consider the environmental costs, i.e., costs associated with environmental damages imposed on society giving rise to the failure with respect to externalities (Nguyen, Laratte, Guillaume, \& Hua, 2016). Such environmental costs involve the reduction in air quality, the contribution to climate change, and the impacts on public health. Looking at coal externalities, for instance, Epstein et al. (2011) estimate that the overall cost of such externalities ranges from 9 to 27 cents per kilowatthour $(\mathrm{kWh})$ of electricity generated, with an average of about 18 cents per $\mathrm{kWh}^{2}$. It represents a cautious approximation, since the authors do not take all associated impacts into consideration. Undoubtedly, internalizing these negative impacts or environmental costs in the prices of market products is a great challenge to support long term business activities in order to pave the way for sustainability (Brandão \& Weidema, 2013). From this perspective, accounting for environmental externalities is of paramount importance for setting the optimal price level; thus, environmental externalities should be monetized whenever possible for the appraisal of the economic costs (Bemow, Biewald, \& Marron, 1991).

Several approaches to deal with environmental externalities have been proposed in literature, encompassing quantitative methods (cost of damages, cost of control), qualitative methods (qualitative treatment) and hybrid methods (weighting and ranking) (Blokhin, 2018). ELCA is a hybrid method for the appraisal of the environmental impacts occurring along the whole life cycle of a product from extraction of raw materials to its end of life. ELCA allows characterizing the externalities towards different impact categories according to the environmental impacts they are expected to provide (e.g. climate change, human toxicity, ozone depletion, etc.). Some of the weighting methods in ELCA are built to assign an economic value to the environmental impacts (i.e. monetization approaches) providing a result in monetary terms. The big challenge will be to design an "economic tool" able to adequately account for the socio-environmental costs associated to fossil-based products' externalities.

Considering that most of these external factors do not affect the majority of renewable energy sources, the rational of internalization, is to make people aware about the unsustainability of fossilbased products and encourage them to change their behavior towards new environmentally friendly models of production and consumption. Moreover, the effective internalization of externalities would 
change the relative price of traditional products (i.e. fossil based) in favor of green counterparts, making them even more appealing for consumers (Nguyen et al., 2016).

\subsection{Consumer Acceptance and Demand for Bio-Based Products}

The third source of uncertainty is strongly linked to the demand side, since consumers face uncertainties and risks associated with the development of new products (Ferrari, Morone, \& Tartiu, 2016). Understanding how consumers react to adoption may help to persuade firms to make the decision to adopt green reverse logistics (Rogers, 2003). Specifically, understanding the consumers perception of risk and uncertainty with respect to their personal values, has important effects on their willingness to pay for green products (Russo, Confente, Scarpi, \& Hazen, 2019). Notably, the health and safety of consumers appears to be the factor that most influences the consumer's willingness to pay for bio-based products (Falcone \& Imbert, 2018).

Willingness to pay is also strongly related to social acceptability which might represent a dramatic barrier for market uptake. (McCormick \& Kautto, 2013). Social acceptability might be triggered by means of the available information of product performance (Martin et al., 2018). However, there is a lack of standardized social indicators for social performance measurements. The development of general social indicators could provide organizations with relevant information to better understand those social factors that might influence the market acceptability of a product (Lamberton, 2005). This, in turn, would support empirical experience and accordingly contribute to the development of the bio-based economy (Kühnen \& Hahn, 2017). Moreover, the use of social indicators can assist decision makers in providing a fit-forpurpose social sustainability scheme, including standards, labels and certifications, based on the product-related impacts on the wellbeing of different stakeholders' categories (Jørgensen, Dreyer, \& Wangel, 2012). This is in line with literature on green product development proving that consumers, when confronted with eco-friendly purchase alternatives, respond not only rationally but also emotionally (Koenig-Lewis, Palmer, Dermody, \& Urbye, 2014).

\subsection{Circular Economy and Other Sustainable Pathways}

The circular economy approach has the goal to make better use of resources/materials through reuse, recycling and recovery, and also to minimise the energy and environmental impact of resource extraction and processing (Masi, Rizzo, \& Regelsberger, 2018). Basically, it denotes new business models which aim at creating industrial systems which are purposely restorative, by reducing unintended negative consequences on the environment of production and consumption processes (Genovese, Acquaye, Figueroa, \& Koh, 2017). With the aim of effectively addressing such challenges, sustainability innovations must renovate mainstream practices (Werbeloff, Brown, \& Loorbach, 2016) by including renewable resources, reverse logistics, eco-efficiency, green supply chain and the involvement of the entire supply chain (de Vargas Mores, Finocchio, Barichello, \& Pedrozo, 2018).

Defining effective ways to align sustainable supply chain practices to circular economy paradigm represent cutting edge topics at the intersection of scientific research and public policy (De Angelis, Howard, \& Miemczyk, 2018). In this regard, a sustainable supply chain is not just concerned with the reduction of environmental concerns within the organizations but with a paradigm shift in production philosophy (Howard, Hopkinson, \& Miemczyk, 2018). As a consequence, a number of sustainable pathways can coexist and be combined. Just think about the single-use conventional plastics, which have led to radical changes in people's lifestyles. The replacement of such material with bioplastics would be only partially a sound solution as a sustainable bio-based economy would not be compatible with current levels of consumption. Therefore, the above-mentioned alternative consumption and ownership models deserve close attention also in the context of the bio-based economy (Morone, Falcone, \& Lopolito, 2019; Vainio, Ovaska, \& Varho, 2019). 


\section{DISCUSSION}

As the authors argued above, when considering bio-based products sustainability, a variety of perspectives should be embraced. Indeed, there is a need for research to deepen how the bio-based economy could advance through a greater harmonization with other sustainable production and consumption patterns.

Moreover, in order to boost the development and market uptake of sustainable bio-based products, encompassing the adoption of a more efficient cascading approach, a proactive action from a wide variety of public and private actors is needed (Mengal et al., 2018). This includes setting an adequate legislative framework. In this respect, standards can play a crucial role in strengthening the current regulatory framework and can represent a basis for public procurement (De Besi \& McCormick, 2015) and provide the first step towards the creation of labels (Ladu \& Blind, 2017). In particular, underpinning the use of standards can lead to overcome a wide range of barriers including mitigating investment risk and improving access to markets. More specifically, the development of standards can generally contribute to: i) increasing economic efficiency by boosting the development of economies of scale; ii) overcoming market failures stemming from asymmetric information between the supply and consumer sides by developing information, measurement and minimum quality standards.

However, despite having made important progress in the standardization of bio-based products, as emphasized in section 3.1, these standards have not yet been fully put into effect by governments of Member States to create incentives and/or market pull initiatives and have still not been provided with defined thresholds (BBP EG, 2017). Moreover, legally binding sustainability criteria are applied only to some bio-based products, leading to leakage effects, limited compatibility between existing sustainability certification schemes and thereby to a lack of harmonization (Majer et al. 2018). With the increase of the cascading-use approach and consequently the increasing interaction among different value chains, a more harmonised approach to sustainability certifications must be supported (Bennich \& Belyazid, 2017).

\section{CONCLUSION}

International institutions are calling for a transition towards more sustainable systems of production and consumption. The production of innovative bio-based products, i.e. products wholly or partly derived from materials of biological origin, deriving from innovative production processes and/or innovative biomass such as food waste or forest residuals, is part of this process. However, while the European Commission since the launch of the Bioeconomy Strategy is supporting the production of renewable biological resources and their conversion into value added products and bio-energy, several issues remain about the sustainability of bio-based products there are also issues about sustainability of biobased products along the whole life cycle, from feedstock provision to end-of-life (InnProBio, 2018).

In sum, managing risks and accounting for uncertainty entails multidisciplinary tools and approaches, reflecting all the different perspectives and issues described above. Since the sector is constantly updated on account of new knowledge of bio-based products impacts, policy makers must be able to balance the development of a coherent policy framework, through the development of sustainability schemes and standards, which gives security to investors but also remain flexible enough to adapt to the acquisition of new information (Purkus, Hagemann, Bedtke, \& Gawel, 2018). With this in mind, the specular aspect on the consumption side should be duly taken into account when designing a sustainability scheme. It is necessary to introduce criteria that take into account the consumption side and not only that of the production side. For example, by considering the expected lifetime of a product, therefore if it goes in the direction of the reuse. Hence, a new perspective which brings technological and behavioral aspects together while balancing different sustainability pillars (i.e., at the same time taking into account environmental, social and economic aspects) is of paramount importance. Against this background, a double symmetric sustainability is needed, bearing in mind that 
there is no "one-size-fits all" formula since not all the criteria used for a sustainability assessment are suited to every product category. In this perspectives, government policies such as excise tax credits or accelerated depreciation should help bio-based industry development by increasing profitability and reducing risk (Pereira, Dias, MacLean, \& Bonomi, 2015).

\section{ACKNOWLEDGMENT}

The authors are very grateful to the STAR-ProBio project (Sustainability Transition Assessment and Research of Bio-based Products) for their financial support. The project is funded by the European Union's Horizon 2020 Research and Innovation Programme under Grant Agreement 727740, Work Programme BB-01-2016: Sustainability schemes for the bio-based economy. 


\section{REFERENCES}

Aven, T. (2010). On how to define, understand and describe risk. Reliability Engineering \& System Safety, 95(6), 623-631. doi:10.1016/j.ress.2010.01.011

BBP EG. (2017). Final Report on biobased products.

Bemow, S., Biewald, B., \& Marron, D. (1991). Environmental externalities measurement: quantification, valuation and monetization. In External Environmental Costs of Electric Power (pp. 81-102). Springer. doi:10.1007/9783-642-76712-8_7

Ben-Iwo, J., Manovic, V., \& Longhurst, P. (2016). Biomass resources and biofuels potential for the production of transportation fuels in Nigeria. Renewable \& Sustainable Energy Reviews, 63, 172-192. doi:10.1016/j. rser.2016.05.050

Bennich, T., \& Belyazid, S. (2017). The route to sustainability-Prospects and challenges of the bio-based economy. Sustainability, 9(6), 887. doi:10.3390/su9060887

Blokhin, A. (2018). How do economists measure externalities? Investopedia. Retrieved from https://www. investopedia.com/ask/answers/043015/how-do-economists-measure-positive-and-negative-externalities.asp

Bosch, S., \& Schmidt, M. (2019). Is the post-fossil era necessarily post-capitalistic? - The robustness and capabilities of green capitalism. Ecological Economics, 161, 270-279. doi:10.1016/j.ecolecon.2019.04.001

Brandão, M., \& Weidema, B. P. (2013). Conceptual challenges for internalising externalities. In Proceedings of the 6th International Conference on Life Cycle Management (pp. 205-208). Academic Press.

Brown, M. A. (2001). Market failures and barriers as a basis for clean energy policies. Energy Policy, 29(14), 1197-1207. doi:10.1016/S0301-4215(01)00067-2

Carus, M., Raschka, A., Iffland, K., Dammer, L., Essel, R., \& Piotrowski, S. (2016). How to shape the next level of the European bio-based economy. In The Reasons for the Delay and the Prospects of Recovery in Europe. Academic Press.

Corrado, S., \& Sala, S. (2018). Bio-Economy Contribution to Circular Economy. In Designing Sustainable Technologies, Products and Policies (pp. 49-59). Springer. doi:10.1007/978-3-319-66981-6_6

De Angelis, R., Howard, M., \& Miemczyk, J. (2018). Supply chain management and the circular economy: Towards the circular supply chain. Production Planning and Control, 29(6), 425-437. doi:10.1080/09537287 .2018.1449244

de Assis, C. A., Gonzalez, R., Kelley, S., Jameel, H., Bilek, T., Daystar, J., \& Singh, D. et al. (2017). Risk management consideration in the bioeconomy. Biofuels, Bioproducts \& Biorefining, 11(3), 549-566. doi:10.1002/ bbb. 1765

De Besi, M., \& McCormick, K. (2015). Towards a bioeconomy in Europe: National, regional and industrial strategies. Sustainability, 7(8), 10461-10478. doi:10.3390/su70810461

de Vargas Mores, G., Finocchio, C. P. S., Barichello, R., \& Pedrozo, E. A. (2018). Sustainability and innovation in the Brazilian supply chain of green plastic. Journal of Cleaner Production, 177, 12-18. doi:10.1016/j. jclepro.2017.12.138

Dubois, O., \& Gomez San Juan, M. (2016). How sustainability is addressed in official bioeconomy strategies at international, national and regional levels: An overview. FAO.

Epstein, P. R., Buonocore, J. J., Eckerle, K., Hendryx, M., Stout Iii, B. M., Heinberg, R., \& Ahern, M. M. et al. (2011). Full cost accounting for the life cycle of coal. Annals of the New York Academy of Sciences, 1219(1), 73-98. doi:10.1111/j.1749-6632.2010.05890.x PMID:21332493

European Commission. (2018a). A Clean Planet for all - A European long-term strategic vision for a prosperous, modern, competitive and climate neutral economy.

European Commission. (2018b). A new bioeconomy strategy for a sustainable Europe. Retrieved from https:// ec.europa.eu/commission/news/new-bioeconomy-strategy-sustainable-europe-2018-oct-11-0_en 
Falcone, P. M., García, S. G., Imbert, E., Lijó, L., Moreira, M. T., \& Tani, A. .. Morone, P. (2019). Transitioning towards the bio-economy: Assessing the social dimension through a stakeholder lens. Corporate Social Responsibility and Environmental Management. doi:10.1002/csr.1791

Falcone, P. M., \& Imbert, E. (2017). Bringing a sharing economy approach into the food sector: The potential of food sharing for reducing food waste. In Food Waste Reduction and Valorisation (pp. 197-214). Academic Press. doi:10.1007/978-3-319-50088-1_10

Falcone, P. M., \& Imbert, E. (2018). Social life cycle approach as a tool for promoting the market uptake of biobased products from a consumer perspective. Sustainability (Switzerland), 10(4), 1031. doi:10.3390/su10041031

Farley, J., \& Daly, H. E. (2011). Ecological economics: Principles and applications. Island Press.

Ferrari, A., Morone, P., \& Tartiu, V. (2016). Tackling Uncertainty through Business Plan Analysis-A Case Study on Citrus Waste Valorisation in the South of Italy. Agriculture, 6(1), 5. doi:10.3390/agriculture6010005

Genovese, A., Acquaye, A. A., Figueroa, A., \& Koh, S. C. L. (2017). Sustainable supply chain management and the transition towards a circular economy: Evidence and some applications. United Kingdom: Omega. doi:10.1016/j.omega.2015.05.015

Hagemann, N., Gawel, E., Purkus, A., Pannicke, N., \& Hauck, J. (2016). Possible futures towards a wood-based bioeconomy: A scenario analysis for Germany. Sustainability, 8(1), 98. doi:10.3390/su8010098

Howard, M., Hopkinson, P., \& Miemczyk, J. (2018). The regenerative supply chain: A framework for developing circular economy indicators. International Journal of Production Research, 1-19.

Hubbard, D. W. (2009). The failure of risk management: Why it's broken and how to fix it. John Wiley \& Sons.

Imbert, E. (2017). Food waste valorization options: Opportunities from the bioeconomy. Open Agriculture, 2(1), 195-204. doi:10.1515/opag-2017-0020

Ingrao, C., Bacenetti, J., Bezama, A., Blok, V., Goglio, P., Koukios, E. G., \& Zabaniotou, A. et al. (2018). The potential roles of bio-economy in the transition to equitable, sustainable, post fossil-carbon societies: Findings from this virtual special issue. Journal of Cleaner Production, 204, 471-488. doi:10.1016/j.jclepro.2018.09.068

InnProBio. (2018). Factsheet No. 2 Sustainability of bio-based products.

Jørgensen, A., Dreyer, L. C., \& Wangel, A. (2012). Addressing the effect of social life cycle assessments. The International Journal of Life Cycle Assessment, 17(6), 828-839. doi:10.1007/s11367-012-0408-9

Koenig-Lewis, N., Palmer, A., Dermody, J., \& Urbye, A. (2014). Consumers' evaluations of ecological packaging-Rational and emotional approaches. Journal of Environmental Psychology, 37, 94-105. doi:10.1016/j. jenvp.2013.11.009

Krugman, P., Wells, R., \& Graddy, K. (2007). Economics (European Edition). Macmillan.

Kühnen, M., \& Hahn, R. (2017). Indicators in social life cycle assessment: A review of frameworks, theories, and empirical experience. Journal of Industrial Ecology, 21(6), 1547-1565. doi:10.1111/jiec.12663

Ladu, L., \& Blind, K. (2017). Overview of policies, standards and certifications supporting the European biobased economy. Current Opinion in Green and Sustainable Chemistry, 8, 30-35.

Laibach, N., Börner, J., \& Bröring, S. (2019). Exploring the future of the bioeconomy: An expert-based scoping study examining key enabling technology fields with potential to foster the transition toward a bio-based economy. Technology in Society, 58, 101118. doi:10.1016/j.techsoc.2019.03.001

Lamberton, G. (2005). Sustainability accounting-A brief history and conceptual framework. Accounting Forum, 29(1), 7-26. doi:10.1016/j.accfor.2004.11.001

Martin, C. J. (2016). The sharing economy: A pathway to sustainability or a nightmarish form of neoliberal capitalism? Ecological Economics, 121, 149-159. doi:10.1016/j.ecolecon.2015.11.027

Martin, M., Røyne, F., Ekvall, T., \& Moberg, ̊. (2018). Life cycle sustainability evaluations of bio-based value chains: Reviewing the indicators from a Swedish perspective. Switzerland: Multidisciplinary Digital Publishing Institute. doi:10.3390/su10020547 
Masi, F., Rizzo, A., \& Regelsberger, M. (2018). The role of constructed wetlands in a new circular economy, resource oriented, and ecosystem services paradigm. Journal of Environmental Management, 216, 275-284. doi:10.1016/j.jenvman.2017.11.086 PMID:29224716

McCormick, K., \& Kautto, N. (2013). The Bioeconomy in Europe: An Overview. Sustainability, 5(6), 2589-2608. doi:10.3390/su5062589

Mengal, P., Wubbolts, M., Zika, E., Ruiz, A., Brigitta, D., Pieniadz, A., \& Black, S. (2018). Bio-based Industries Joint Undertaking: The catalyst for sustainable bio-based economic growth in Europe. New Biotechnology, 40, 31-39. doi:10.1016/j.nbt.2017.06.002 PMID:28666809

Meyer, R. (2017). Bioeconomy strategies: Contexts, visions, guiding implementation principles and resulting debates. Sustainability, 9(6), 1031. doi:10.3390/su9061031

Morone, P., Falcone, P. M., Imbert, E., \& Morone, A. (2018). Does food sharing lead to food waste reduction? An experimental analysis to assess challenges and opportunities of a new consumption model. Journal of Cleaner Production, 185, 749-760. doi:10.1016/j.jclepro.2018.01.208

Morone, P., Falcone, P. M., \& Lopolito, A. (2019). How to promote a new and sustainable food consumption model: A fuzzy cognitive map study. Journal of Cleaner Production, 208, 563-574. doi:10.1016/j.jclepro.2018.10.075

Mounce, R., \& Nelson, J. D. (2019). On the potential for one-way electric vehicle car-sharing in future mobility systems. Transportation Research Part A, Policy and Practice, 120, 17-30. doi:10.1016/j.tra.2018.12.003

Muradian, R. (2019). Frugality as a choice vs. frugality as a social condition. Is de-growth doomed to be a Eurocentric project? Ecological Economics, 161, 257-260. doi:10.1016/j.ecolecon.2019.03.027

Nguyen, T. L. T., Laratte, B., Guillaume, B., \& Hua, A. (2016). Quantifying environmental externalities with a view to internalizing them in the price of products, using different monetization models. Resources, Conservation and Recycling, 109, 13-23. doi:10.1016/j.resconrec.2016.01.018

Pereira, L. G., Dias, M. O. S., MacLean, H. L., \& Bonomi, A. (2015). Investigation of uncertainties associated with the production of n-butanol through ethanol catalysis in sugarcane biorefineries. Bioresource Technology, 190, 242-250. doi:10.1016/j.biortech.2015.04.095 PMID:25958148

Pfau, S., Hagens, J., Dankbaar, B., \& Smits, A. (2014). Visions of sustainability in bioeconomy research. Sustainability, 6(3), 1222-1249. doi:10.3390/su6031222

Poyry. (2016). The Recarbonisation Trilogy Poyri Point of view. Retrieved from https://www.poyry.com/sites/ default/files/media/related_material/0029_recarbonisation_trilogy_web.pdf

Priefer, C., Jörissen, J., \& Frör, O. (2017). Pathways to shape the bioeconomy. Resources, 6(1), 10. doi:10.3390/ resources 6010010

Purkus, A., Hagemann, N., Bedtke, N., \& Gawel, E. (2018). Towards a sustainable innovation system for the German wood-based bioeconomy: Implications for policy design. Journal of Cleaner Production, 172, 3955-3968. doi:10.1016/j.jclepro.2017.04.146

Richardson, B. (2012). From a fossil-fuel to a biobased economy: The politics of industrial biotechnology. Environment and Planning. C, Government \& Policy, 30(2), 282-296. doi:10.1068/c10209

Rogers, E. M. (2003). Diffusion of Innovations (5th ed.). New York, NY: Simon \& Schuster, Inc.

Russo, I., Confente, I., Scarpi, D., \& Hazen, B. (2019). From trash to treasure: The impact of consumer perception of bio-waste products in closed-loop supply chains. Journal of Cleaner Production, 218, 966-974. doi:10.1016/j. jclepro.2019.02.044

Sheppard, A. W., Gillespie, I., Hirsch, M., \& Begley, C. (2011). Biosecurity and sustainability within the growing global bioeconomy. Current Opinion in Environmental Sustainability, 3(1-2), 4-10. doi:10.1016/j. cosust.2010.12.011

Spekreijse, J., Lammens, T., Parisi, C., Ronzon, T., \& Vis, M. (2019). Insights into the European market for bio-based chemicals Factsheets for 10 bio-based product categories. Retrieved from https://publications.jrc. ec.europa.eu/repository/bitstream/JRC115202/jrc_europeanmarket_biochemicals_factsheet_online.pdf 
Staffas, L., Gustavsson, M., \& McCormick, K. (2013). Strategies and policies for the bioeconomy and bio-based economy: An analysis of official national approaches. Sustainability, 5(6), 2751-2769. doi:10.3390/su5062751

Teece, D., Peteraf, M., \& Leih, S. (2016). Dynamic capabilities and organizational agility: Risk, uncertainty, and strategy in the innovation economy. California Management Review, 58(4), 13-35. doi:10.1525/cmr.2016.58.4.13

Turner, R. K., Pearce, D., \& Bateman, I. (1994). Environmental economics: an elementary introduction. Harvester Wheatsheaf.

Vainio, A., Ovaska, U., \& Varho, V. (2019). Not so sustainable? Images of bioeconomy by future environmental professionals and citizens. Journal of Cleaner Production, 210, 1396-1405. doi:10.1016/j.jclepro.2018.10.290

van den Oever, M., \& Molenveld, K. (2017). Replacing fossil based plastic performance products by biobased plastic products-Technical feasibility. New Biotechnology, 37, 48-59. doi:10.1016/j.nbt.2016.07.007 PMID:27445201

Vose, D. (2008). Risk analysis: a quantitative guide. John Wiley \& Sons.

Werbeloff, L., Brown, R. R., \& Loorbach, D. (2016). Pathways of system transformation: Strategic agency to support regime change. Environmental Science \& Policy, 66, 119-128. doi:10.1016/j.envsci.2016.08.010

Zsóka, Á., Szerényi, Z. M., Széchy, A., \& Kocsis, T. (2013). Greening due to environmental education? Environmental knowledge, attitudes, consumer behavior and everyday pro-environmental activities of Hungarian high school and university students. Journal of Cleaner Production, 48, 126-138. doi:10.1016/j. jclepro.2012.11.030

\section{ENDNOTES}

$1 \quad$ Market failures can be viewed as scenarios where individual's pursuit of pure self-interest leads to results that are not efficient - that can be improved upon from the societal point of view (Krugman, Wells, \& Graddy, 2007).

2 It represents a conservative estimate, because they have not accounted for every associated impact.

Pasquale Marcello Falcone is Assistant Professor of Economic Policy at Department of Business and Economics, Parthenope University of Naples. He obtained a PhD in Economics at University of Foggia (Italy) and an MSc in Economics at University of Leicester (UK). His core research interest concerns the understanding of the mechanisms through which transitions towards a bio-based economy can be intertwined with socio-economic and policy aspects. Recently he is exploring the role of policy instruments in the transition towards a bio-based economy.

Enrica Imbert $(P h D)$ works on topics related to sustainable development by applying innovative tools such as Social Network Analysis. She obtained a PhD in 'Economic Development, Finance and International Cooperation' at Sapienza University in 2015. She is a Researcher at Unitelma-Sapienza and currently her research focus is on issues related to the market uptake of bio-based products. 